\title{
Results from the First-Round of Bangladesh Environmental Technology Verification - Support to Arsenic Mitigation (BETV-SAM) Field Test
}

\author{
Ali S.-Amiri*a, E. Morsheda ${ }^{a}$, A. I. Kazi ${ }^{\text {b }}$, S. Siraj ${ }^{\text {b }}$ S. Ahmed ${ }^{b}$ and M. A. Akborb \\ a Ontario Centre for Environmental Technology Advancement (OCETA), 2070 Hadwen Road, Unit 201A, \\ Mississauga, Ontario, Canada, L5K 2C9 and ${ }^{b}$ Bangladesh Council of Scientific and Industrial Research, Dr. \\ Qudrat-I-Khoda Road, Dhanmondi, Dhaka, Bangladesh
}

\begin{abstract}
The Bangladesh Environmental Technology Verification - Support to Arsenic Mitigation (BETV-SAM) program objectively assessed thirteen arsenic removal technologies (ARTs) that had been submitted for performance verification, and selected seven technologies for the field testing and performance verification. Each technology was deployed to five hydrogeologically distinct regions of Bangladesh and was tested on five wells (with replicate units installed and tested on two wells). Raw and treated water samples were collected at regular intervals and were analysed for arsenic and other water quality parameters. The data were analysed using standard statistical software and the performance of individual ARTs have been evaluated and compared with the proponent's claim. Two technologies (STAR \& CIWP) performed well while five other technologies performed poorly and their claims were rejected. The results of the first-round of the BETV-SAM field testing and performance verification program presented and discussed in this paper, may be important from a technological design and development point of view.
\end{abstract}

Key words: Arsenic removal technology, Field testing, Performance verification, Water quality parameters.

\section{Introduction}

Arsenic contamination of groundwater in Bangladesh is widespread and acute and an estimated 30 million Bangladeshi (Heikens 2006) obtain their drinking water from shallow tubewells that are contaminated with arsenic above the national drinking water standard of $50 \mathrm{mg} / \mathrm{l}$ (Government of Bangladesh [GoB], 1997). Arsenic is poisonous and a known cancer causing agent (Centeno et al. 2002, Loewenberg 2007) and approximately 10,000 - 30,000 Bangladeshis have already been diagnosed with arsenicosis (Heikens 2006). Thus, meeting the need for arsenic-safe 3 drinking water in Bangladesh is urgent.

Approximately 30\% of shallow tubewells in Bangladesh are contaminated with concentrations of arsenic in the range of $100-1000 \mu \mathrm{g} / \mathrm{L}$. The occurrence of high concentrations of arsenic is often associated with elevated levels of iron, phosphate, and manganese. A recent survey found that more than $80 \%$ of arsenic-affected tubewells (i.e. [As] $>50 \mu \mathrm{g} / \mathrm{l}$ ) also contain equal or greater than $2 \mathrm{mg} / \mathrm{l}$ of iron (Ahmed, 2001; Ahmed, 2003). In areas with an acute iron problem, the iron concentrations in wells can reach more than $10 \mathrm{mg} / \mathrm{l}$.
A variety of Arsenic Removal Technologies (ARTs) could be employed to remove arsenic from arsenic contaminated groundwater; however, the technologies may not last long, perform as well as expected, and may not produce as much arsenic-safe water as expected. The technologies that were marketed in Bangladesh in the past had not been tested adequately and appropriately in the country and their performance claims are not guaranteed. The international community was also reluctant to deploy those ARTs to address the problem associated with the shortage of arsenic-safe drinking water, due to potential liabilities associated with the use of technologies that might not work "as advertised".

The Government of Bangladesh (GoB) sought means of validating the performance of any ART before permitting it to be marketed and sold in the country and designated the Bangladesh Council of Scientific and Industrial Research (BCSIR) as the national verification authority. The Bangladesh Environmental Technology Verification-Support to Arsenic Mitigation (BETV-SAM) program, a bilateral

* Corresponding author: E-mail: amiri.s.ali@gmail.com

${ }^{3}$ The term arsenic-safe refers to potable water with arsenic concentrations below the permissible Bangladesh drinking water standard level of $50 \mu \mathrm{g} / \mathrm{L}$. 
project between the Governments of Bangladesh and Canada, was established in order to verify that ARTS: A) demonstrate the ability to consistently produce potable water with arsenic concentrations below $50 \mu \mathrm{g} / \mathrm{l}$ from arsenic-contaminated well water at a prescribed minimum daily volume, B) produce the quantity of arsenic-safe water the proponents claim that their technologies are able to generate, and C) don't add harmful substances to the treated water. In addition, the BETV-SAM also analysed treated water for other regulated species, such as manganese, boron, etc.

Thirteen candidate ARTs registered through BCSIR for performance verification in the first round. None of the proponent provided sufficient, independent, and verifiable data that could be used to verify their performance claim. Therefore, there was the need to field test each technology to collect independent, credible and verifiable data in order to be able to evaluate technology performance and to either verify or reject a technology proponent's claim. After screening all applications, the BETV-SAM program, in its firstround of field testing and performance verification, selected, deployed, and field tested seven (7) ARTs in five hydrogeologically different regions of Bangladesh.

In addition to arsenic, groundwater in Bangladesh is often contaminated with iron, phosphate, manganese, and other inorganic species. Removal of these latter species has important implications for the technology performance and can be achieved through proper design and O\&M procedures. The influence of water quality parameters, removal of iron dissolved in groundwater, and other O\&M procedures on ARTs performance are discussed in the paper.

\section{Materials and Methods}

\section{A. Technology Screening and Selection}

The program screened and ranked all ARTs on the basis of available experimental data for arsenic removal ability, ease of operation and maintenance, ability to treat well water with different concentrations of dissolved iron, phosphate, silicate, alkalinity, etc., and other technical requirements and selected seven ARTs for the field testing and performance verification. These include Apyron, Canadian International Water Purification Limited (CIWPL), MAGC/Alcan (referred to as Alcan afterwards), Nelima, Shapla, STAR, and Wholly Water. Nelima and Shapla were developed locally and the rest were either imported from overseas or the media and concepts were developed abroad and the units were designed and built locally. The CIWPL and STAR employ coagulant, ferric sulphate, and the rest employ arsenic adsorption media for the capture and removal of arsenic dissolved in groundwater. The types and quantity of media and/or coagulants employed by each technology and their modes of operations are presented in Table I.

\section{B. Testing Procedures}

When applied for performance verification, each technology proponent made a performance claim, which specified that: a) the ART can produce arsenic-safe, potable water from arsenic contaminated groundwater that contains known concentrations of As, iron, phosphate, silicate, sulphate $\left(\mathrm{SO}_{4}{ }^{2-}\right)$, etc, and within a certain range of $\mathrm{pH}$, and b) the technology can generate $\mathrm{X}$ and $\mathrm{Y}$ litres of arsenic-safe water in a day (or per batch) and over the useful lifespan of the media (for ARTs that employ sorption media), respectively.

\section{Table I: The types of media and the production capacities of different ARTs}

\begin{tabular}{l|l|l|l|l}
\hline Technology & Media & Quantity & Polishing Media & Operation \\
\hline Apyron & $\begin{array}{l}\text { Alumina and } \\
\text { Modified Alumina }\end{array}$ & $48.0-63.0 \mathrm{~kg}$ & $\begin{array}{l}\text { Granular Activated } \\
\text { Carbon (GAC) }\end{array}$ & Flow-Through \\
CIWPL & Ferric Sulphate & $200-600 \mathrm{mg} / 20 \mathrm{~L}$ & Special slow CIWP sand filter & Batch \\
Alcan & Modified Alumina & $40 \mathrm{~kg}$ & None & Flow-Through \\
Nelima & Granular Ferric Oxide & $1.0 \mathrm{~kg}$ & Sand filter & Batch \\
Shapla & $\mathrm{Fe}_{2} \mathrm{O}_{3}$ impregnated Brick chip & $40.0 \mathrm{~kg}$ & None & Batch \\
STAR & Ferric Sulphate & $1.5 \mathrm{~g} / 20 \mathrm{~L}$ & Sand and GAC & Flow-Through \\
Wholly Water & MnO & GaC/Modified alumina & \\
& Reducing agent and Alumina & & & \\
\hline
\end{tabular}


The BETV-SAM program in consultation with proponents developed Technology Specific Test Plans (TSTP) for each technology and tested each technology on five wells (35 wells in total) in Chapai, Dohar, Kolaroa, Ishwardi, and in Nabinagar. The wells, selected for field testing and performance verification in each area, met proponents' water quality criteria such as concentrations of $\mathrm{As}, \mathrm{PO}_{4}{ }^{3-}, \mathrm{Fe}, \mathrm{pH}$, etc, as well as the ease of access, free from the influence of point sources of pollution, and availability of space for testing, etc.

The technologies were installed either by proponents or by field staff that were trained by proponents. Each technology was operated and maintained following proponents Operation and Maintenance (O\&M) procedures. The coagulation-flocculation technologies were tested for $10-20$ days and the adsorption technologies were operated until: a) arsenic breakthrough (i.e. effluent [As])> $50 \mu \mathrm{g} / \mathrm{l}$ ) occurred, or b) produced enough arsenic-safe water and met the proponent's performance claim. A brief description of each technology and the operating procedures is provided here.

\section{ALCAN}

The ALCAN ARTs consist of two trapezoidal tanks (approximate dimensions: $0.46 \mathrm{~m} \times 0.46 \mathrm{~m} \times 0.46 \mathrm{~m}$ ) that are piped together and each tank houses about $20 \mathrm{~kg}$ of arsenic removal media. The media was covered with a perforated plate and a furnace filter and were suspended off the bottom of the tank by a perforated acrylic sheet. During the normal operation, the tubewell water was pumped, at a flow rate of $\leq 5 \mathrm{l} / \mathrm{min}$, directly into the first tank using an electrical pump. The water flows in a down-flow mode through the first tank and an up-flow mode through the second one. The media was backwashed at least once a week for approximately 15 minutes to remove silts, sands, and iron flocs.

\section{Apyron}

An Apyron ART consists of a chlorination chamber for the oxidation and removal of dissolved iron as well as arsenite, a $25 \mathrm{~cm} \times 165 \mathrm{~cm}$ PVC column that houses media (three different types of media that were packed in three different layers in the column), flow distribution plates, and frits. The unit was connected to a pump that was in turn attached to the well head. The well water was pumped, at a flow rate of $<10$ $1 /$ min, directly into the unit in a downward direction, and treated effluent water was collected in a container or released into the field. The unit was backwashed periodically in order to remove accumulated silts, sands, and iron flocs and to restore normal flow rate.

\section{Wholly Water}

A Wholly Water ART unit consists of an electrical pump, two arsenic removal filters, an overhead tank, a backwash tank, and other accessories. The first arsenic removal filter was filled with four different layers of manganese dioxide, brass powders, ferric sulfate modified alumina, and granular activated carbons successively from top to the bottom. The second filter was only filled with modified alumina. The well water was pumped into the overhead tank and was then spiked with sodium hypochlorite to oxidize and remove dissolved iron. The pre-treated water was then flowed into the arsenic filtration units at a flow rate $\leq 4 \mathrm{l} / \mathrm{min}$ and the treated water was either collected in a clean container or released into the field. The filter was regularly backwashed for at least 10 minutes and at a rate of approximately $4 \mathrm{l} / \mathrm{min}$ for the removal of accumulated silts, sands, and iron flocs and restoration of normal flow rate.

\section{Nelima}

The Nelima ART consists of two 30 L buckets, each with a lid and a water tap that was attached on the sidewall and slightly above the bottom, a sand filter, and an arsenic removal filter. The two buckets are placed one above the other, on a folding tripod steel stand. The top bucket was perforated along the brim and its lid was fitted with a PVC rod that extended into the bucket. The sand filter was placed in the bottom of the top bucket, and the arsenic removal filter was placed in the bottom bucket. The filters and water taps were connected to each other with flexible rubber tubing. During normal operation, the water taps on both the top and bottom buckets were closed, the lid from the top bucket was removed and approximately $20 \mathrm{~L}$ of well water was poured into the top bucket. The lid was re-secured and the solution was stirred with the PVC rod about 3 or 4 times to increase the aeration rate and to accelerate the oxidation and flocculation. If the influent water contained more than 3 $\mathrm{mg} / \mathrm{l}$ of dissolved iron, the water was allowed to stand in the top bucket for approximately 1.5 to 2 hours. Otherwise, the water tap on the top bucket was opened and the pretreated water flowed to the lower bucket, through first the sand filter and then the sand arsenic removal filter, and accumulated in the lower bucket, which acts as a reservoir for the treated water.

\section{Shapla}

The Shapla ART consists of two earthenware columns, approximately $56 \mathrm{~cm} \times 87 \mathrm{~cm}$ each, with two lids of the 
same materials and a single point of water delivery system. Each column housed approximately $20 \mathrm{~kg}$ of filter media. Each column was filled slowly with about $12 \mathrm{~L}$ of well water and the water was allowed to flow through the column by carefully opening the draining valve and allowing treated water to leave the column. The Shapla ART was operated intermittently, in a batch-flow mode, with an average flow rate of $5.5 \mathrm{l} / \mathrm{h}$. The unit was able to treat about 24 litres of contaminated water in approximately 4.3 hours and was operated twice in 12 hours, with two hours resting period in between.

\section{STAR}

The STAR ART consists of two empty buckets, one of which contains the clean, coarse filter sand media and is fitted near the bottom with a spout, flexible tubing, and packets of the reagent chemical which is composed of ferric sulphate and calcium hypochlorite. In a normal operation, the empty bucket was filled with approximately $16 \mathrm{~L}$ of well water, a packet of chemical reagent was added, the solution was mixed well with a clean stick for one minute, and allowed to stand for approximately 10 - 15 minutes. It was then gently poured through an inverted plastic bottle whose bottom was cut-off onto the sand filter in the filtration bucket to remove the suspended solids, including the arsenic-containing iron flocs. Water was drained from the sand filter bucket.

\section{CIWPL}

The CIWP ART consist of the filter apparatus (NSF food grade PVC piping and CIWPL sand filter media), reagent chemical (ferric sulphate and 5\% sodium hypochlorite solution), a rod to stir the raw water after chemical additions, a ladle to remove solids from suspension, two raw water buckets and a food grade bucket for collection of arsenic-safe water, and an additional bucket for sludge collection. In a normal operation, approximately $20 \mathrm{~L}$ of well water was added to a plastic bucket, spiked with sufficient volumes of sodium hypochlorite such that a distinct chlorine odour is detected after stirring the bucket. This was followed by the addition of 200, 400, or $600 \mathrm{mg}$ of ferric sulfate to well water containing $<1 \mathrm{mg} / \mathrm{l}, 1-2 \mathrm{mg} / \mathrm{L}$, or $>2 \mathrm{mg} / \mathrm{l}$ of phosphate, respectively. The solution was stirred for about two minutes, allowed to stand for an hour, and filtered through a filter assembly to remove the suspended solids, including the arsenic containing iron hydroxide particulates.

\footnotetext{
${ }^{4}$ The designated laboratories were selected amongst laboratories that are located in Dhaka, participated in a round-robin sample analysis prior to the field testing, and performed well.

${ }^{5}$ Bacteriological samples were analysed for faecal coliform; $10 \%$ were tested for total coliform.
}

\section{Sampling and Analysis}

During the testing period, samples were taken at regular intervals and were analysed for concentrations of arsenic, iron, phosphate, silicate, alkalinity, bacterial contamination, total metal scan, etc. following the procedures outlined below.

* Total Arsenic Analysis: Five (5) to seven (7) raw groundwater samples and 10 - 20 treated groundwater samples were collected from each technology and analysed for total arsenic (using atomic absorption spectroscopyhydrate generation (AAS-HG) procedures) in one of the designated analytical laboratories ${ }^{4}$ following the Standard Procedures (Clesceri et al. 1998), thereby ensuring that both the influent and effluent water were sufficiently characterised.

* As(III), Total Iron, Phosphate and Microbial Analyses: At least three influent and three effluent samples are collected from each technology and analyzed in one of the designated analytical laboratories in Bangladesh for concentrations of $\mathrm{As}(\mathrm{III}), \mathrm{Fe}$ (total), $\mathrm{PO}_{4}{ }^{3-}$, and faecal and total coliforms ${ }^{5}$ following Standard Procedures (Clesceri et al. 1998). samples were analysed in the field for alkalinity and chlorine (for ARTs that employed chlorine) analysis. In addition, the $\mathrm{pH}$, conductivity, and turbidity of 5 influent samples and 10 treated effluent samples were measured using portable meters, following standard protocols. The $\mathrm{pH}$ and conductivity were measured employing a Hach Multimeter, model Sension 156, Chlorine was measured using a Hach Chlorine (total) test kit model CN-66T, Turbidity was measured with a Hach Turbidimeter model 2100, and alkalinity was determined with a Hach Alkalinity test kit model AL-AP MG-L.

* QA/QC Samples: Duplicate, field blank, and reference standard samples were also collected and sent to the Maxxam Analytical Laboratory, Mississauga, Ontario, Canada, an ISO 17025 certified analytical laboratory, for $\mathrm{QA} / \mathrm{QC}$ purposes. Sample analysis at Maxxam was performed employing inductively coupled plasma - mass spectrometry (ICP-MS) (Clesceri et al. 1998).

* Other Water Quality Parameters: A number of influent and effluent water samples were also collected and analysed for anions, metal scan (Reference Lab using
* Field Analyses: Five (5) influent and five (5) effluent 
ICP-MS techniques), and volatile organic compounds and chlorinated phenols (for ARTs employing chlorine). A summary of the analytical methods employed for the BETV-SAM field testing program are outlined in Table II.
Where appropriate, the effluent arsenic data has been analysed statistically using MINITAB14 statistical software to show that: a) the data are randomly distributed around a mean value prior to arsenic breakthrough, and $b$ ) the mean

Table II: Summary of Sampling Requirements and Analytical Methods

\begin{tabular}{|c|c|c|c|c|c|}
\hline Parameter & $\begin{array}{c}\text { Sample } \\
\text { volume }(\mathrm{mL})\end{array}$ & Reference Method & Preservation & $\begin{array}{l}\text { Recommended } \\
\text { Storage time }\end{array}$ & Field QC \\
\hline Total As - lab & 100 & Standard Method & Acidify with & 2 months & $\mathrm{B}, \mathrm{D}^{7}$ \\
\hline $\begin{array}{l}\text { analysis } \\
\text { As(III) }\end{array}$ & 100 & $\begin{array}{l}\text { 3114 B } \\
\text { Standard Method } \\
3114 \text { B }\end{array}$ & $\begin{array}{l}\mathrm{HNO}_{3} \text { to } \mathrm{pH}<2 \\
\text { Acidify with } \\
\mathrm{HNO}_{3} \text { to } \mathrm{pH}<2\end{array}$ & 2 months & $\mathrm{B}, \mathrm{D}$ \\
\hline Total Fe & 100 & $\begin{array}{l}\text { Standard Method; } \\
\text { Spectrophotometery }\end{array}$ & $\begin{array}{l}\text { Acidify with } \mathrm{HNO}_{3} \\
\text { to } \mathrm{pH}<2\end{array}$ & 6 months & B,D \\
\hline Orthophosphate $\left(\mathrm{PO}_{4}{ }^{3-}\right)$ & 100 & Spectrophotometry & $\begin{array}{l}\text { Acidify with } \mathrm{HNO}_{3} \\
\text { to } \mathrm{pH}<2\end{array}$ & 48 hours & B,D \\
\hline Metal scan ${ }^{8}$ & 100 & $\begin{array}{l}\text { ICP-AES, ICP-MS or } \\
\text { ICP-AAS }\end{array}$ & $\begin{array}{l}\text { Acidify with } \\
\mathrm{HNO}_{3} \text { to } \mathrm{pH}<2\end{array}$ & 6 months & B,D \\
\hline Anion scan & 100 & Ion Chromatography & $\begin{array}{l}\text { Refrigerate at } 4^{\circ} \mathrm{C} \text {, } \\
\text { keep in the dark }\end{array}$ & 48 hours & $\mathrm{B}, \mathrm{D}$ \\
\hline Faecal and total Coliforms & 200 & $\begin{array}{l}\text { Membrane Filter } \\
\text { method }\end{array}$ & Refrigerate at $4^{\circ} \mathrm{C}$ & 24 hours & B,D \\
\hline Sulphate $\left(\mathrm{SO}_{4}{ }^{2-}\right)$ & 100 & Ion Chromatography & $\begin{array}{l}\text { Refrigerate at } 4^{\circ} \mathrm{C} \text {, } \\
\text { keep in the dark }\end{array}$ & 48 hours & B,D \\
\hline Total As - field analysis & 50 & $\begin{array}{l}\text { Arsenator }{ }^{\mathrm{TM}} \text { portable } \\
\text { test kit }\end{array}$ & Not applicable (NA) & At the well site & $\mathrm{B}, \mathrm{D}$ \\
\hline $\mathrm{pH}$, turbidity, conductivity & 200 & Use Hach field kits & NA & At the well site & NA \\
\hline Alkalinity & 200 & Hach kit & NA & At the well site & NA \\
\hline
\end{tabular}

${ }^{6}$ Recommended storage times are maximum storage times. For best analytical results, samples should be analysed as soon as possible.

${ }^{7}$ Blank and Duplicate samples are collected and analysed.

${ }^{8}$ Metals scan includes all required parameters, including $\mathrm{Al}, \mathrm{Ca}, \mathrm{Cr}, \mathrm{K}, \mathrm{Mn}, \mathrm{Na}, \mathrm{Si}$, and $\mathrm{U}$.

${ }^{9}$ Field tests were carried out as soon as possible after sampling.

* Arsenic-Safe Water Production Capacity: The field testing program measured the rate of production of treated water (l/h and l/day) and cumulative volume (CV) of water that was generated by each technology over the duration of the technology testing period (for technologies that employ sorptive media), respectively. The effluent arsenic concentrations ([As $]_{\mathrm{T}}$ ) on each well site were plotted against the cumulative volume of treated water (for sorption technologies) or against days of technology operation (for coagulation technologies). The data were then analyzed using MINITAB14 statistical software to find the correlation between $[\mathrm{As}]_{\mathrm{T}}$ and $\mathrm{CV}$ or days of technology operation. effluent arsenic concentration prior to breakthrough is less than $50 \mu \mathrm{g} / \mathrm{l}$ with $95 \%$ confidence.

\section{Results and Discussions}

Each proponent made a performance claim when it applied for the technology performance verification. The performance claims for each of the seven technologies that were tested by the BETV-SAM program are presented in Table III and the range of concentrations of As, $\mathrm{Fe}, \mathrm{PO}_{4}{ }^{3-}$, and the $\mathrm{pH}$ of well waters selected for different ARTs are presented in Tables IV - X. The data clearly demonstrate that: a) wells selected for each technology met water quality parameters specified by the vendors in almost all cases, and b) water quality parameters covered a range of values from low to 
Table III: The performance claims of ARTs

\begin{tabular}{l|l|l|l|l|l|l}
\hline ART $\backslash W Q P$ & {$[\mathrm{As}] / \mu \mathrm{g} / \mathrm{l}$} & {$[\mathrm{Fe}] / \mathrm{mg} / \mathrm{l}$} & {$\left[\mathrm{PO}_{4}{ }^{3-}\right] / \mathrm{mg} / \mathrm{l}$} & $\mathrm{pH}$ & $\begin{array}{l}\text { Daily/Batch } \\
\text { Capacity }\end{array}$ & $\begin{array}{l}\text { Total } \\
\text { Capacity }\end{array}$ \\
\hline Apyron & $\leq 1,200$ & $\leq 10$ & $\leq 5$ & $5.0-8.0$ & $4800 \mathrm{~L} /$ day & $160,000 \mathrm{~L}$ \\
CIWPL & $\leq 1000$ & $\leq 20.0$ & $\leq 10.0$ & $\mathrm{C}^{10}$ & $20 \mathrm{~L} / \mathrm{batch}$ & $\mathrm{NA}$ \\
Alcan & 1,500 & $\mathrm{Any}$ & 5 & $\mathrm{C}$ & $2400 \mathrm{~L} /$ day & $80,000 \mathrm{~L}$ \\
Nelima & $\leq 350$ & $<4$ & $<10$ & $5.5-8.0$ & $20 \mathrm{~L} / \mathrm{batch}$ & $8,000 \mathrm{~L}$ \\
Shapla & $450-700$ & $\leq 40.0$ & $\leq 4.0$ & $\mathrm{C}$ & $24 \mathrm{~L} / \mathrm{batch}$ & $7,000 \mathrm{~L}$ \\
STAR & $\leq 750$ & $\leq 21$ & $\leq 10$ & $\mathrm{C}$ & $20 \mathrm{~L} / \mathrm{batch}$ & $\mathrm{NA}$ \\
Wholly Water & $\leq 1000$ & $\leq 10$ & $\leq 6$ & $5.5-8.5$ & $2080 \mathrm{~L} / \mathrm{d}$. & $295,000 \mathrm{~L}$ \\
\hline
\end{tabular}

Table IV: Summary of the well water quality parameters for Apyron; Replicate units were installed on wells in Chapai and Kolaroa

\begin{tabular}{l|c|c|c|c|c}
\hline $\begin{array}{l}\text { Location and } \\
\text { Well Number }\end{array}$ & $\begin{array}{c}{[\mathrm{As}] / \mu \mathrm{g} / \mathrm{l}} \\
\text { Mean } \pm \mathrm{CI}^{11}\end{array}$ & $\begin{array}{c}{[\mathrm{As}(\mathrm{III})] /} \\
{[\mathrm{As}]_{\mathrm{T}}}\end{array}$ & $\begin{array}{c}{\left[\mathrm{Fe}^{+2}\right] / \mathrm{mg} / \mathrm{l}} \\
\text { Mean } \pm \mathrm{CI}\end{array}$ & $\begin{array}{c}{\left[\mathrm{PO}_{4}{ }^{3-}\right] / \mathrm{mg} / \mathrm{l}} \\
\text { Mean } \pm \mathrm{CI}\end{array}$ & $\begin{array}{c}\mathrm{pH} \\
\text { Mean } \pm \mathrm{CI}\end{array}$ \\
\hline Chapai/W21 & $866 \pm 156$ & 0.80 & $0.6 \pm 0.3$ & $0.4 \pm 0.1$ & $7.12 \pm 0.27$ \\
Dohar/W52 & $265 \pm 32$ & 0.93 & $13.0 \pm 0.1$ & $3.8 \pm 0.3$ & $7.05 \pm 0.11$ \\
Ishwardi/W65 & $900 \pm 120$ & 0.73 & $7.8 \pm 2.2$ & $1.2 \pm 1.2$ & $6.93 \pm 0.04$ \\
Kolaroa/W07 & $228 \pm 25$ & 0.91 & $5.0 \pm 1.0$ & $3.8 \pm 0.9$ & $7.14 \pm 0.13$ \\
Nabinagar/W75 & $344 \pm 42$ & 1.08 & $4.5 \pm 0.8$ & $7.9 \pm 0.5$ & $7.31 \pm 0.50$ \\
\hline
\end{tabular}

Table V: Summary of the well water quality parameters for CIWPL; Replicate units were installed on wells in Chapai and Nabinagar

\begin{tabular}{l|c|c|c|c|c}
\hline $\begin{array}{l}\text { Location and } \\
\text { Well Number }\end{array}$ & $\begin{array}{c}{[\mathrm{As}] / \mu \mathrm{g} / \mathrm{l}} \\
\text { Mean } \pm \mathrm{CI}\end{array}$ & $\begin{array}{c}{[\mathrm{As}(\mathrm{III})] /} \\
{[\mathrm{As}]_{\mathrm{T}}}\end{array}$ & $\begin{array}{c}{\left[\mathrm{Fe}^{+2}\right] / \mathrm{mg} / \mathrm{l}} \\
\text { Mean } \pm \mathrm{CI}\end{array}$ & $\begin{array}{c}{\left[\mathrm{PO}_{4}{ }^{3-}\right] / \mathrm{mg} / \mathrm{l}} \\
\text { Mean } \pm \mathrm{CI}\end{array}$ & $\begin{array}{c}\mathrm{pH} \\
\text { Mean } \pm \mathrm{CI}\end{array}$ \\
\hline Chapai/W21 & $622 \pm 23$ & 0.76 & $3.3 \pm 0.5$ & $1.1 \pm 0.2$ & $7.02 \pm 0.14$ \\
Dohar/W31 & $348 \pm 31$ & 0.82 & $11.3 \pm 3.9$ & $4.6 \pm 0.6$ & $7.23 \pm 0.17$ \\
Kolaroa/W07 & $295 \pm 7$ & 0.94 & $8.6 \pm 0.4$ & $2.4 \pm 0.3$ & $6.60 \pm 0.24$ \\
Ishwardi/W65 & $482 \pm 37$ & $1.01^{12}$ & $4.7 \pm 0.5$ & $1.5 \pm 0.3$ & $6.97 \pm 0.04$ \\
Nabinagar/W20 & $323 \pm 14$ & $1.04^{12}$ & $5.1 \pm 0.3$ & $7.5 \pm 0.3$ & $7.38 \pm 0.32$ \\
\hline
\end{tabular}

${ }^{10} \mathrm{C}$ - Circumneutral pH $\quad{ }^{11} \mathrm{CI}$ is Confidence Interval; Mean \pm CI shows 95\% confidence intervals

12 These are probably too high because of analytical error

Table VI: Summary of the well water quality parameters for MAGC/ALCAN; Replicate units were installed on wells in Chapai and Kolaroa

\begin{tabular}{l|c|c|c|c|c}
\hline $\begin{array}{l}\text { Location and } \\
\text { Well Number }\end{array}$ & $\begin{array}{c}{[\mathrm{As}] / \mu \mathrm{g} / \mathrm{l}} \\
\text { Mean } \pm \mathrm{CI}\end{array}$ & $\begin{array}{c}{[\mathrm{As}(\mathrm{III})] /} \\
{[\mathrm{As}]_{\mathrm{T}}}\end{array}$ & $\begin{array}{c}{\left[\mathrm{Fe}^{+2}\right] / \mathrm{mg} / \mathrm{l}} \\
\text { Mean } \pm \mathrm{CI}\end{array}$ & $\begin{array}{c}{\left[\mathrm{PO}_{4}{ }^{3-}\right] / \mathrm{mg} / \mathrm{l}} \\
\text { Mean } \pm \mathrm{CI}\end{array}$ & $\begin{array}{c}\mathrm{pH} \\
\text { Mean } \pm \mathrm{CI}\end{array}$ \\
\hline Chapai/W21 & $519 \pm 13$ & $1.0^{13}$ & $0.9 \pm 0.3$ & $0.2 \pm 0.1$ & $7.02 \pm 0.11$ \\
Dohar/W52 & $358 \pm 35$ & 0.86 & $6.9 \pm 0.8$ & $2.9 \pm 0.2$ & $7.02 \pm 0.18$ \\
Ishwardi/W65 & $1151 \pm 310$ & 0.80 & $10.2 \pm 1.8$ & $1.0 \pm 0.5$ & $6.91 \pm 0.05$ \\
Kolaroa/W07 & $257 \pm 50$ & 0.95 & $7.9 \pm 0.5$ & $4.5 \pm 1.1$ & $7.10 \pm 0.12$ \\
Nabinagar/W75 & $396 \pm 50$ & 0.85 & $3.0 \pm 0.4$ & $7.9 \pm 1.0$ & $7.64 \pm 0.16$ \\
\hline
\end{tabular}

13 This is high because of the analytical error involved in measuring As concentration 
Table VII: Summary of the well water quality parameters for Nelima; Replicate units were installed on wells in Chapai and Dohar

\begin{tabular}{l|c|c|c|c|c}
\hline $\begin{array}{l}\text { Location and } \\
\text { Well Number }\end{array}$ & $\begin{array}{c}{[\mathrm{As}] / \mu \mathrm{g} / \mathrm{l}} \\
\text { Mean } \pm \mathrm{CI}\end{array}$ & $\begin{array}{c}{[\mathrm{As}(\mathrm{III})] /} \\
{[\mathrm{As}]_{\mathrm{T}}}\end{array}$ & $\begin{array}{c}{\left[\mathrm{Fe}^{+2}\right] / \mathrm{mg} / \mathrm{l}} \\
\text { Mean } \pm \mathrm{CI}\end{array}$ & $\begin{array}{c}{\left[\mathrm{PO}_{4}{ }^{3-}\right] / \mathrm{mg} / \mathrm{l}} \\
\text { Mean } \pm \mathrm{CI}\end{array}$ & $\begin{array}{c}\mathrm{pH} \\
\mathrm{Mean} \pm \mathrm{CI}\end{array}$ \\
\hline Chapai/W24 & $274 \pm 10$ & 0.8 & $4.2 \pm 0.8$ & $1.4 \pm 0.3$ & $7.06 \pm 0.07$ \\
Dohar/W57 & $283 \pm 20$ & 0.83 & $2.3 \pm 0.3$ & $1.1 \pm 0.2$ & $7.05 \pm 0.25$ \\
Ishwardi/W93 & $269 \pm 38$ & $1.00^{12}$ & $2.3 \pm 0.2$ & $0.8 \pm 0.3$ & $6.85 \pm 0.03$ \\
Kolaroa/W07 & $301 \pm 16$ & 0.90 & $8.6 \pm 0.6$ & $2.4 \pm 0.6$ & $6.69 \pm 0.23$ \\
Nabinagar/W60 & $221 \pm 12$ & $1.00^{12}$ & $1.2 \pm 0.1$ & $2.4 \pm 0.1$ & $7.66 \pm 0.20$ \\
\hline
\end{tabular}

Table VIII: Summary of the well water quality parameters for Shapla; Replicate units were installed on wells in Chapai and Dohar

\begin{tabular}{l|c|c|c|c|c}
\hline $\begin{array}{l}\text { Location and } \\
\text { Well Number }\end{array}$ & $\begin{array}{c}{[\mathrm{As}] / \mu \mathrm{g} / \mathrm{l}} \\
\text { Mean } \pm \mathrm{CI}\end{array}$ & $\begin{array}{c}{[\mathrm{As}(\mathrm{III})] /} \\
{[\mathrm{As}]_{\mathrm{T}}}\end{array}$ & $\begin{array}{c}{\left[\mathrm{Fe}^{+2}\right] / \mathrm{mg} / \mathrm{l}} \\
\text { Mean } \pm \mathrm{CI}\end{array}$ & $\begin{array}{c}{\left[\mathrm{PO}_{4}{ }^{3-}\right] / \mathrm{mg} / \mathrm{l}} \\
\text { Mean } \pm \mathrm{CI}\end{array}$ & $\begin{array}{c}\mathrm{pH} \\
\text { Mean } \pm \mathrm{CI}\end{array}$ \\
\hline Chapai/W24 & $278 \pm 17$ & 0.80 & $4.3 \pm 0.8$ & $1.5 \pm 0.2$ & $7.10 \pm 0.05$ \\
Dohar/W57 & $283 \pm 20$ & 0.83 & $2.3 \pm 0.3$ & $1.1 \pm 0.2$ & $7.16 \pm 0.39$ \\
Ishwardi/W93 & $269 \pm 38$ & $0.97^{12}$ & $2.1 \pm 0.4$ & $0.8 \pm 0.1$ & $6.90 \pm 0.04$ \\
Kolaroa/W07 & $301 \pm 16$ & 0.89 & $8.7 \pm 0.8$ & $3.2 \pm 0.2$ & $6.90 \pm 0.30$ \\
Nabinagar/W60 & $221 \pm 12$ & 0.61 & $1.2 \pm 0.1$ & $2.3 \pm 0.2$ & $7.52 \pm 0.33$ \\
\hline
\end{tabular}

Table IX: Summary of the well water quality parameters for STAR; Replicate units were installed on wells in Chapai and Nabinagar

\begin{tabular}{l|c|c|c|c|c}
\hline $\begin{array}{l}\text { Location and } \\
\text { Well Number }\end{array}$ & $\begin{array}{c}{[\mathrm{As}] / \mu \mathrm{g} / \mathrm{l}} \\
\text { Mean } \pm \mathrm{CI}\end{array}$ & $\begin{array}{c}{[\mathrm{As}(\mathrm{III})] /} \\
{[\mathrm{As}]_{\mathrm{T}}}\end{array}$ & $\begin{array}{c}{\left[\mathrm{Fe}^{+2}\right] / \mathrm{mg} / \mathrm{l}} \\
\text { Mean } \pm \mathrm{CI}\end{array}$ & $\begin{array}{c}{\left[\mathrm{PO}_{4}^{3-}\right] / \mathrm{mg} / \mathrm{l}} \\
\text { Mean } \pm \mathrm{CI}\end{array}$ & $\begin{array}{c}\mathrm{pH} \\
\text { Mean } \pm \mathrm{CI}\end{array}$ \\
\hline Chapai/W31 & $621 \pm 3$ & 0.76 & $3.1 \pm 0.1$ & $1.0 \pm 0.1$ & $7.02 \pm 0.13$ \\
Dohar/W21 & $347 \pm 40$ & 0.82 & $12.6 \pm 0.6$ & $4.5 \pm 0.8$ & $7.02 \pm 0.56$ \\
Kolaroa/W07 & $298 \pm 11$ & 0.94 & $8.5 \pm 0.4$ & $2.3 \pm 0.5$ & $6.95 \pm 0.06$ \\
Ishwardi/W65 & $526 \pm 53$ & $1.01^{12}$ & $4.6 \pm 0.5$ & $1.4 \pm 0.2$ & $6.97 \pm 0.05$ \\
Nabinagar/W75 & $355 \pm 15$ & $1.04^{12}$ & $3.1 \pm 0.2$ & $10.4 \pm 0.8$ & $7.36 \pm 0.36$ \\
Nabinagar/W20 & $309 \pm 23$ & $1.04^{12}$ & $5.2 \pm 0.3$ & $7.9 \pm 0.4$ & $7.45 \pm 0.34$ \\
\hline
\end{tabular}

Table X: Summary of the well water quality parameters for Wholly Water; Replicate units were installed on wells in Chapai and Kolaroa

\begin{tabular}{l|c|c|c|c|c}
\hline $\begin{array}{l}\text { Location and } \\
\text { Well Number }\end{array}$ & $\begin{array}{c}{[\mathrm{As}] / \mu \mathrm{g} / \mathrm{l}} \\
\text { Mean } \pm \mathrm{CI}\end{array}$ & $\begin{array}{c}{[\mathrm{As}(\mathrm{III})] /} \\
{[\mathrm{As}]_{\mathrm{T}}}\end{array}$ & $\begin{array}{c}{\left[\mathrm{Fe}^{+2}\right] / \mathrm{mg} / \mathrm{l}} \\
\text { Mean } \pm \mathrm{CI}\end{array}$ & $\begin{array}{c}{\left[\mathrm{PO}_{4}{ }^{3-}\right] / \mathrm{mg} / \mathrm{l}} \\
\text { Mean } \pm \mathrm{CI}\end{array}$ & $\begin{array}{c}\mathrm{pH} \\
\text { Mean } \pm \mathrm{CI}\end{array}$ \\
\hline Chapai/W21 & $675 \pm 23$ & 0.84 & $1.1 \pm 0.4$ & $1.6 \pm 0.2$ & $7.19 \pm 0.24$ \\
Dohar/W52 & $420 \pm 22$ & 0.72 & $5.45 \pm 0.4$ & $2.8 \pm 0.7$ & $7.18 \pm 0.35$ \\
Ishwardi/W65 & $641 \pm 75$ & 0.98 & $4.1 \pm 0.6$ & $0.5^{14}$ & $7.04 \pm 0.14$ \\
Kolaroa/W07 & $239 \pm 17$ & 0.93 & $4.7 \pm 0.9$ & $4.0 \pm 0.4$ & $6.97 \pm 0.56$ \\
Nabinagar/W75 & $341^{14}$ & 0.43 & $5.2^{14}$ & $7.4 \pm 1.7$ & $7.44 \pm 0.60$ \\
\hline
\end{tabular}

14 Average of two measurements and hence no precision is reported for these data 
Table XI: Summary of statistical analysis (t-statistic) of effluent arsenic concentrations in Apyron treated water samples, prior to arsenic breakthrough, in different locations.

\begin{tabular}{l|c|c|c|c}
\hline Location/Unit & Mean effluent [As]/ $\mu$ g/L; Mean \pm CI & Treated water volume/L & Claimed Volume/ L & Claim Status \\
\hline Chapai/U3 & $2.0 \pm 2.4$ & 61,300 & 175,000 & Denied \\
Chapai/U7 & $1.5 \pm 0.7$ & 63,500 & 175,000 & Denied \\
Dohar/U1 & $31 \pm 11$ & 169,300 & 175,000 & Verified \\
Ishwardi/U4 & $3.0^{15}$ & 27,119 & 175,000 & Denied \\
Kolaroa/U2 & $4.5^{15}$ & 42,149 & 175,000 & Denied \\
Kolaroa/U6 & $20.0^{15}$ & 44,743 & 175,000 & Denied \\
Nabinagar/U7 & $5.0^{15}$ & 37,224 & 175,000 & Denied \\
\hline
\end{tabular}

15 Average of two to three measurements

Table XII: Summary of statistical analysis (t-statistic) of arsenic concentrations in CIWPL treated water samples in different locations.

\begin{tabular}{l|c|c|c|c}
\hline Location/Unit & No. of Data Points & Mean effluent [As]/ $\mu$ g/l; Mean \pm CI & $\mathrm{P}^{16}$ & 0.008 \\
\hline Chapai/U3 & 14 & $37.1 \pm 8.9$ & 0.030 & Claim Status \\
Chapai/U6 & 19 & $37.9 \pm 10.7$ & 0.000 & Verified \\
Dohar/U1 & 13 & $7.7 \pm 1.3$ & 0.000 & Verified \\
Ishwardi/U4 & 12 & $14.7 \pm 4.2$ & 0.000 & Verified \\
Kolaroa/U2 & 13 & $7.2 \pm 1.1$ & 0.249 & Verified \\
Nabinagar/U5 & 11 & $60.0 \pm 18.2$ & 0.907 & Denied \\
Nabinagar/U7 & 10 & $50.7 \pm 14$ & & Denied \\
\hline
\end{tabular}

Table XIII: Summary of statistical analysis (t-statistic) of arsenic concentrations in Alcan treated water samples, prior to arsenic breakthrough, in different locations.

\begin{tabular}{l|c|c|c|c}
\hline Location/Unit & Mean effluent [As]/ $\mu$ g/L; Mean \pm CI & Treated water volume/L & Claimed Volume/ L & Claim Status \\
\hline Chapai/U3 & $25.4 \pm 8.4$ & $\geq 81,000$ & 80,000 & Verified \\
Chapai/U7 & $27.9 \pm 16.0$ & $\sim 40,000$ & 80,000 & Denied \\
Dohar/U1 & $26.4 \pm 16.9$ & $\sim 73,000$ & 80,000 & Verified \\
Ishwardi/U4 & $15.7 \pm 11.8^{17}$ & $\sim 8,000$ & 80,000 & Denied \\
Kolaroa/U2 & $39.9 \pm 10$ & $\sim 27,000$ & 80,000 & Denied \\
Kolaroa/U6 & $38.9 \pm 10.5$ & $\sim 23,000$ & 80,000 & Denied \\
Nabinagar/U7 & $39.2 \pm 10.4$ & $\sim 32,000$ & 80,000 & Denied \\
\hline
\end{tabular}

16 The probability of obtaining a sample mean if the true sample mean is really equal to $50 \mathrm{mg} / \mathrm{L}$ as was hypothesized. If the p-value is less than or equal to the corresponding a-level (0.05 in this case), the null hypothesis (mean = $50 \mathrm{mg} / \mathrm{L})$ can be rejected.

17 This is a tentative value since the unit at this location behaved badly from the beginning. 


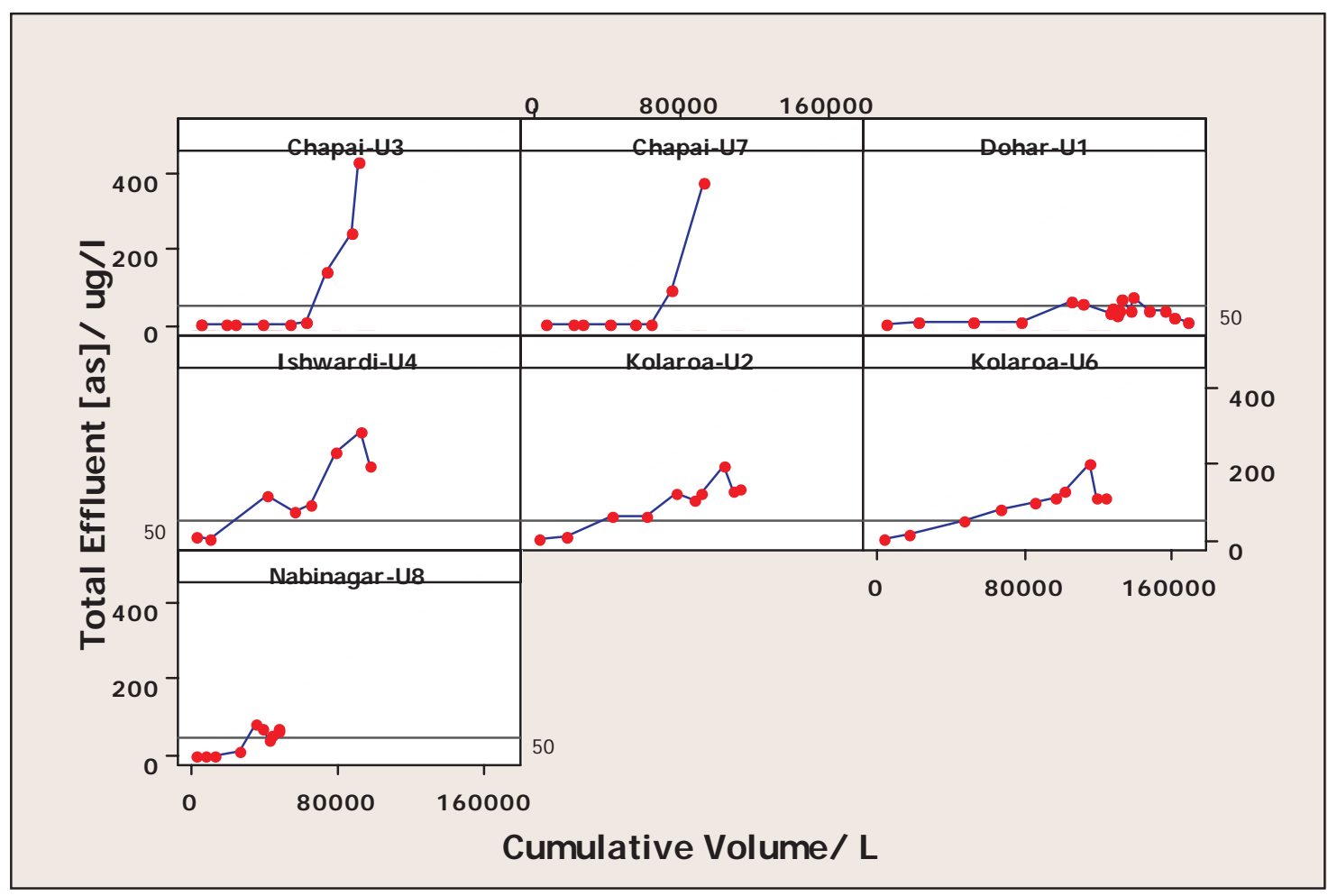

Figure 1: Plots showing effluent As concentrations vs cumulative volume of treated water for a sorption ART. The technology was operated in flow-through mode.

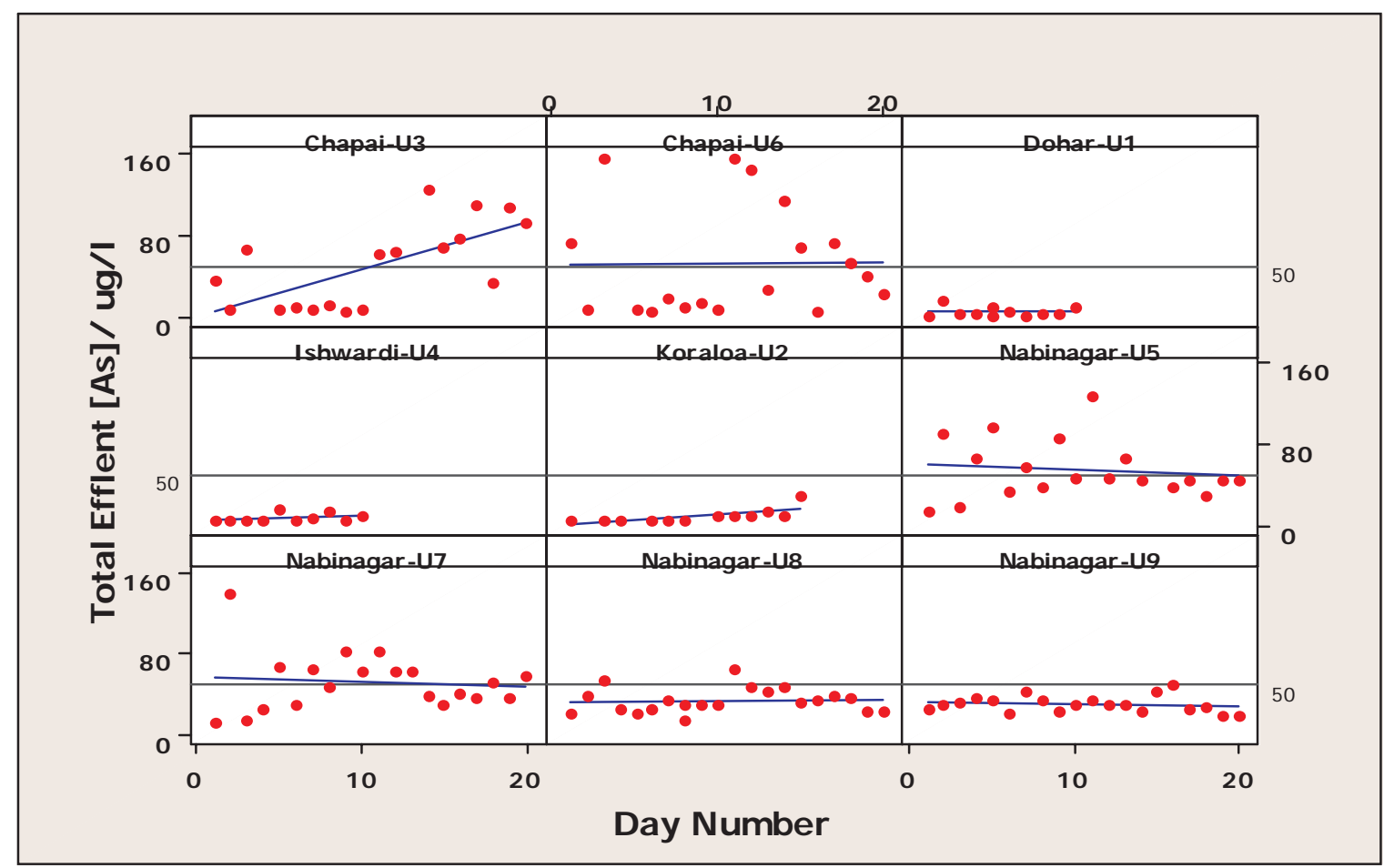

Figure 2: Plots showing effluent As concentrations vs testing days for a coagulation ART 
high and the high values were close to those claimed by the proponents.

All sorptive technologies failed prematurely and did not meet proponents' performance claims while the coagulationflocculation technologies performed well and were able to generate arsenic-safe water as was claimed by their proponents. Typical plots for both the coagulation and sorption technologies are presented in Figures 1 and 2. In general, the effluent arsenic concentrations for the sorption technologies were found to be randomly distributed around a mean value prior to arsenic breakthrough, except in the case of Shapla, where there was an approximate linear relation between $[\mathrm{As}]_{\mathrm{T}}$ and $\mathrm{CV}$. In the case of coagulation technologies, the concentrations of arsenic in the effluent were found to fluctuate around a mean value at each site.

Apyron technology failed prematurely at Chapai, Ishwardi, Kolaroa, and Nabinagar but was able to generate 169,000 L of arsenic-safe potable water in Dohar. The water flow rate at Dohar dropped quickly from the prescribed rate of 10 1/min to around $2 \mathrm{l} / \mathrm{min}$ (perhaps due to filling of the empty bed space by silts, sands, and ferric hydroxide) and the unit was operated at this flow rate for most of the testing period; hence the performance was better at this site. Nelima, Shapla, and Wholly Water technologies performed similarly; the first two technologies failed prematurely on four (4) sites out of five and the last one failed on all five sites.

Two Alcan units, one of the replicates at Chapai and the one in Dohar, performed well and generated $\geq 81,000 \mathrm{~L}$ and about 73,000 L of arsenic-safe potable water, respectively, over the duration of the testing. These two units were backwashed frequently and the effluent after backwashing was discarded for some time because it was found that the concentrations of arsenic in the treated water was high immedi ately after backwashing and decreased gradually to below 50 $\mathrm{mg} / \mathrm{l}$.

The STAR technology performed well on three wells initially and consistently produced arsenic-safe water, failed on the fourth well (replicate units, Nabinagar), and its performance on the fifth well (replicate units, Chapai) could not be confirmed. The failure at Nabinagar was attributed to high concentrations of phosphate $(10.5 \mathrm{mg} / \mathrm{l})$ in this well water. The technology performed well when transferred to and tested on a different well in the same area but with lower phosphate concentration $(7.5 \mathrm{mg} / \mathrm{l})$. The inconsistent performance at Chapai is attributed to operating procedures, a low quantity of sand and sand-boiling as water is poured over the sand by operators. The CIWPL technology also performed well and consistently produced arsenic-safe water on four wells but failed on a well at Nabinagar. This is also attributed to the high concentration of phosphate in this well.

The performances of the two coagulation technologies, CIWP and STAR, were verified while those of the five sorption technologies were denied. Summaries of all field data are presented in Tables XI-XVII.

The failure of the sorption technologies to meet their performance claims and the premature arsenic breakthrough is attributed to the following:

1) These technologies were either not tested with Bangladesh groundwater or tested inadequately by the proponents and the performance claims were not based on realistic field observations.

2) The influence of WQPs such as $\mathrm{Fe}, \mathrm{PO}_{4}{ }^{3-}$, alkalinity, salinity, etc. on technology performance was not considered (Cheng et al. 2004, Meng \& Korfiatis 2001, Meng et al. 2000, Meng et al. 2001, Roberts et al. 2004).

Table XIV: Summary of statistical analysis (t-statistic) of arsenic concentrations in Nelima technology treated water samples, prior to breakthrough, in different locations

\begin{tabular}{l|c|c|c|c}
\hline Location/Unit & Mean effluent [As]/ $\mu$ /L; Mean \pm CI & Treated water volume/L & Claimed Volume/ L & Claim Status \\
\hline Chapai/U3 & $10.0 \pm 19.4$ & 1500 & 8100 & denied \\
Chapai/U7 & $25.3 \pm 10.4$ & 3710 & 8100 & denied \\
Dohar/U1 & $14.0 \pm 23.3$ & $<1000$ & 8100 & denied \\
Dohar/U6 & $8.7 \pm 26.8$ & 790 & 8100 & denied \\
Ishwardi/U4 & $22.9 \pm 10.4$ & 3000 & 8100 & denied \\
Kolaroa/U2 & $21.4 \pm 6.5$ & $>8050$ & 8100 & validated \\
Nabinagar/U5 & $19 \pm 18.5$ & 2890 & 8100 & denied \\
\hline
\end{tabular}

18 Field test was terminated prior to breakthrough, when the technology had produced 8050 L of potable water 
3) Dissolved iron was not removed properly (Ali et al. 2001).

4) The flow rates were often set too high.

5) The O\&M were based on limited laboratory and/or field test data.

The WQPs in general and the concentrations of arsenic, iron, and phosphate in groundwater and groundwater $\mathrm{pH}$ in particular play crucial roles in the performance of the arsenic removal technologies (Cheng et al. 2004, Meng \& Korfiatis 2001, Meng et al. 2000, Meng et al. 2001, Roberts et al. 2004). Ferric oxide/hydroxide and aluminum oxide have limited but reasonable capacities for arsenic adsorption. For example, theoretically, one kilogram of hydroxy ferric oxide (HFO) can adsorb about $148 \mathrm{~g}$ of arsenic (Dzomback \& Mofrel, 1990), which is much higher than the experimentally determined values of (16g As- $40 \mathrm{~g} \mathrm{As}) /(\mathrm{kg}$ of HFO) (Hussam et al. 2003, Pal 2001, Pierce \& Moore 1982).
Aluminum oxide, on the other hands, adsorbs a lower quantity of arsenic: a kilogram of Aluminum oxide adsorbs about $4 \mathrm{~g}$ of arsenic (ALCAN 2006). These values indicated that the Alcan, Apyron, Wholly Water, and Nelima ARTs should be able to generate $\geq 4 \times 10^{5} \mathrm{~L}, 3.2 \times 10^{5} \mathrm{~L}, 2.2 \times 10^{5} \mathrm{~L}$ and $11000 \mathrm{~L}$ of arsenic-safe water, respectively, from groundwater contaminated with $500 \mathrm{mg} / \mathrm{l}$ of As. The above estimations assume that iron and phosphate dissolved in groundwater do not affect media capacity, which is an incorrect assumption. Dissolved iron should assist (Meng \& Korfiatis 2001) and phosphate should hinder (Roberts et al. 2004) arsenic removal ability of adsorption media. For example, our field observations show that the oxidation and removal of iron naturally present in water can remove up to $75 \%$ of arsenic dissolved in groundwater.

Iron dissolved in groundwater can have both positive and negative effects on media capacity. The half-life of iron dissolved in groundwater, $\mathrm{Fe}(\mathrm{II})$, at circumneutral $\mathrm{pH}$ and in the

Table XV: Summary of statistical analysis (t-statistic) of arsenic concentrations in Nelima technology treated water samples, prior to breakthrough, in different locations

\begin{tabular}{l|c|c|c}
\hline Location/Unit & Treated water volume/L & Claimed Volume/ L & Claim Status \\
\hline Chapai/U3 & $6370 \pm 920$ & 7600 & Verified \\
Chapai/U7 & $4940 \pm 640$ & 7600 & Verified \\
Dohar/U1 & $1020 \pm 370$ & 7600 & Denied \\
Dohar/U6 & $970 \pm 490$ & 7600 & Denied \\
Ishwardi/U4 & $3200 \pm 1200$ & 7600 & Denied \\
Kolaroa/U2 & $1140 \pm 985$ & 7600 & Denied \\
Nabinagar/U5 & $530 \pm 520$ & 7600 & Denied \\
\hline
\end{tabular}

Table XVI: Summary of statistical analysis (t-statistic) of arsenic concentrations in STAR treated water samples in different locations

\begin{tabular}{l|c|c|c|c}
\hline Location/Unit & No. of Data Points & Mean effluent $[\mathrm{As}] / \mu \mathrm{g} / \mathrm{l} ;$ Mean $\pm \mathrm{CI}$ & $\mathrm{P}^{19}$ & Claim Status \\
\hline Chapai/U3 & 19 & $57 \pm 26$ & 0.531 & Denied \\
Chapai/U6 & 19 & $53 \pm 26$ & 0.819 & Denied \\
Dohar/U1 & 17 & $8 \pm 2$ & 0.000 & Verified \\
Ishwardi/U4 & 18 & $9 \pm 4$ & 0.000 & Verified \\
Kolaroa/U2 & 15 & $55 \pm 14$ & 0.000 & Verified \\
Nabinagar/U5 & 20 & $53 \pm 13$ & 0.506 & Denied \\
Nabinagar/U7 & 20 & $35 \pm 5$ & 0.620 & Denied \\
Nabinagar/U8 & 20 & $32 \pm 4$ & 0.000 & Verified \\
Nabinagar/U9 & 19 & & 0.000 & Verified \\
\hline
\end{tabular}

19 The probability of obtaining a sample mean if the true sample mean is really equal to $50 \mathrm{mg} / \mathrm{L}$ as was hypothesized. If the p-value is less than or equal to the corresponding a-level ( 0.05 in this case), the null hypothesis (mean $=50 \mathrm{mg} / \mathrm{L}$ ) can be rejected. 
presence of air is approximately 4 minutes (Hussam et al. 2003). When exposed to air, the ferrous ion, Fe(II), dissolved in groundwater oxidises rapidly to ferric iron, [Fe(III)]. The latter is insoluble in water under circumneutral $\mathrm{pH}$ conditions and hydrolyses rapidly; forming ferric hydroxide (Stumm \& Morgan 1996), which then forms hydroxy ferric oxide (HFO) through coagulation and flocculation processes.

$$
\mathrm{Fe}^{3+}+3 \mathrm{H}_{2} \mathrm{O} \rightarrow \mathrm{Fe}(\mathrm{OH})_{3}+3 \mathrm{H}^{+}
$$

The dissolved arsenic is either trapped within the HFO flocs during floc formation, or adsorbs onto the floc surfaces and subsequently reacts with the surface active -OH group. Both of these processes sequester dissolved arsenic, generate particulate arsenic, and reduce arsenic concentrations in water (Cheng et al. 2004, Meng \& Korfiatis 2001, Meng et al. 2000, Meng et al. 2001, Roberts et al. 2004). In addition to arsenic, HFO can also remove phosphate, fluoride, silicate, etc. (Cheng et al. 2004, Meng \& Korfiatis 2001, Meng et al. 2000, Meng et al. 2001, Roberts et al. 2004).

A Virgin Media Particle

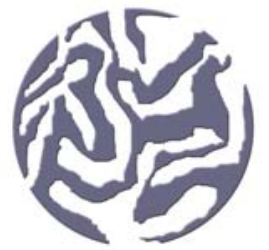

and removal of HFO. The data also show that the concentration of iron was also reduced to below the detection limit of $0.01 \mathrm{mg} / \mathrm{l}$ following filtration and removal of HFO. Although reduction of arsenic concentrations was not significant in all cases, the data never-the-less shows that HFO can end-up in the effluent and bring with it arsenic if not removed.

Phosphate, at concentrations greater than $1 \mathrm{mg} / \mathrm{l}$, is also found in approximately $46 \%$ of the shallow tubewells in Bangladesh that are contaminated with arsenic [Ahmed, 2001 \& 2003). Phosphate is chemically similar to arsenate [As(V)], as indicated by the sorption equilibrium constants (see Eqs. 1 - 4), and competes effectively with the latter for the active sites on the surface of iron hydroxide (Roberts et al. 2004). It is important to note that the sorption constants presented here were calculated using experimental data obtained from the removal of arsenic, phosphate and silicate

A Particle Exposed to Groundwater

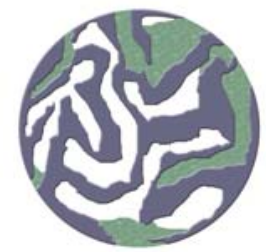

Figure 3: Schematic showing iron oxide filling media cracks and crevasses

The HFO flocs do not adsorb and attach to media. If not removed properly before coming in contact with media, HFO will accumulate in the media cracks and crevasses as illustrated schematically in Figure 3, fill the empty bed spaces (Ali et al 2001), and will slowly wash out into the effluent stream. The net effect of accumulation of iron flocs is blockage of media active sites, blocking of water flow paths and creation of short-cuts that lead to reduced residence times, and reduction of system capacity and premature arsenic breakthrough. This is believed to be partially responsible for the failure of sorption ARTs.

Table XVIII presents concentrations of arsenic and iron in the treated water samples taken from an Alcan and an Apyron unit before and after filtration and removal of HFO, demonstrating that iron flocs can breakthrough the system. The data clearly show that arsenic concentrations in the treated water samples were invariably reduced after filtration by Fe(III), and competitive sorption modeling (Roberts et al. 2004). Thus, the sorption constants provide qualitative comparison of the intrinsic adsorption capacity of HFO for As(V), As(III), phosphate and silicate.

$\begin{array}{lr}\underline{\text { Sorption Equation }} & \frac{\log \mathrm{K}}{5.93} \\ =\mathrm{Fe}-\mathrm{OH}+\mathrm{As}(\mathrm{v}) \leftrightarrow=\mathrm{Fe}-\mathrm{As}(\mathrm{v}) & 4.46 \\ =\mathrm{Fe}-\mathrm{OH}+\mathrm{As}(\mathrm{III}) \leftrightarrow=\mathrm{Fe}-\mathrm{As}(\mathrm{III}) & 6.07 \\ =\mathrm{Fe}-\mathrm{OH}+\mathrm{P} \leftrightarrow=\mathrm{Fe}-\mathrm{P} ; \mathrm{P}=\text { Phosphate } & 6.36\end{array}$

It has been reported that in addition to removing arsenic, HFO also removes $85 \%$ - 99\% of the dissolved phosphate from an aqueous environment (Cheng et al. 2004, Meng \& Korfiatis 2001, Meng et al. 2000, Meng et al. 2001, Mukherjee et al. 2007, Roberts et al. 2004). It is perhaps for this reason that the amount of iron required to remove arsenic from phosphate-contaminated water is much higher than in the absence of phosphate. 
Table XVII: Summary of the performance of Wholly Water ART in Various Locations

\begin{tabular}{l|c|c|c}
\hline Location/Unit & Treated water Volume/L & Claimed Volume/L & Claim Status \\
\hline Chapai/U3 & $<20,000$ & 300,000 & Denied \\
Chapai/U7 & $<20,000$ & 300,000 & Denied \\
Dohar/U1 & $<20,000$ & 300,000 & Denied \\
Ishwardi/U4 & $<20,000$ & 300,000 & Denied \\
Kolaroa/U2 & $<10,000$ & 300,000 & Denied \\
Kolaroa/U6 & $\sim 23,000$ & 300,000 & Denied \\
Nabinagar/U5 & $<10,000$ & 300,000 & Denied \\
\hline
\end{tabular}

Table XVIII: Arsenic and iron concentrations in the Alcan and Apyron effluent before filtration and removal of HFO

\begin{tabular}{|c|c|c|c|}
\hline Technology & Effluent Water & {$[\mathrm{As}] / \mu \mathrm{g} / \mathrm{l}$} & {$[\mathrm{Fe}] / \mathrm{mg} / \mathrm{l}$} \\
\hline \multirow[t]{2}{*}{ Alcan } & Unfiltered & 65 & -- \\
\hline & Filtered & 40 & -- \\
\hline \multirow[t]{2}{*}{ Alcan } & Unfiltered & 51 & 0.5 \\
\hline & Filtered & 47 & $<0.02$ \\
\hline \multirow[t]{2}{*}{ Apyron } & Unfiltered & 235 & -- \\
\hline & Filtered & 190 & -- \\
\hline \multirow[t]{2}{*}{ Apyron } & Unfiltered & 180 & 0.2 \\
\hline & Filtered & 170 & $<0.01$ \\
\hline
\end{tabular}

Other species dissolved in groundwater that could adversely influence the performance of arsenic removal technologies are silicate, fluoride, alkalinity, etc (Cheng et al. 2004, Meeussen et al. 1996, Meng \& Korfiatis 2001, Meng et al. 2000, Meng et al. 2001, Roberts et al. 2004). Silicate and fluoride compete with arsenate and arsenite for the surface active sites, and alkalinity regulates the solution $\mathrm{pH}$, the ionization of $\mathrm{As}(\mathrm{V}), \mathrm{As}(\mathrm{III})$, phosphate ions, and adsorption of these species as well as regulating solubility of -Fe$\mathrm{As}(\mathrm{V}) / \mathrm{As}(\mathrm{III})$ species as illustrated (Dzomback \& Mofrel 1990) by the following equations.

$$
\begin{aligned}
& \mathrm{FeAsO}_{4}+\mathrm{H}^{+} \leftrightarrow \mathrm{Fe}^{3+}+\mathrm{HAsO}_{4}{ }^{2-} \\
& \mathrm{K}=\mathrm{K}_{\mathrm{SP}}(\mathrm{FA}) / \mathrm{K}_{3}(\mathrm{AA})=1.1 \times 10^{-18},\left[\mathrm{HAsO}_{4}{ }^{2-}\right] \\
& =\left\{1.8 \times 10^{-9}\left[\mathrm{H}^{+}\right]\right\}^{1 / 2} \\
& \mathrm{FeAsO}_{4}+3 \mathrm{OH}^{-} \leftrightarrow \mathrm{Fe}(\mathrm{OH})_{3}+\mathrm{AsO}_{4}{ }^{3-} \\
& \mathrm{K}=\mathrm{K}_{\mathrm{SP}}(\mathrm{FA}) / \mathrm{K}_{\mathrm{SP}}(\mathrm{FH})=1.4 \times 10^{17},\left[\mathrm{AsO}_{4}{ }^{3-}\right] \\
& =1.4 \times 10^{+17}\left[\mathrm{OH}^{-}\right]^{3}
\end{aligned}
$$

All sorption ARTs performed well, both in terms of volume of water generated in a day and removal of arsenic from well water, and according to specifications for the first couple of weeks. Surface active sites, easily accessible or buried, are free and available initially. The sites that are easily accessible will be occupied by arsenic leaving inaccessible and hard to reach active sites free. The longer a technology operates the longer the residence time required to reach these latter sites, assuming that they are free and are not blocked by either HFO or the sands and silts pumped from the ground. If not removed, sands and silts will fill the empty bed volume and the cracks and crevasses on media and block access to active sites, create short paths, and reduce arsenic removal efficiency.

\section{Conclusion}

The coagulation technologies performed reasonably well and were able to consistently generate arsenic-safe water in 4 out of the five locations where they were tested. The sorption ARTs, on the other hands, have performed poorly and failed prematurely in most field locations after only a few weeks of operation. The reasons for the failure of these technologies are in part due to the design flows, inadequate field testing in Bangladesh, and inappropriate O\&M procedures.

\section{References}

Ahmed M. F. (2001). An overview of arsenic removal technologies in Bangladesh. In Ahmed, M. F. Ali, M. A. Adeel, Z. (Eds.), Technologies for Arsenic Removal from Drinking Water. Dhaka: Bangladesh University of Engineering Technology and the United Nations University. 
Ahmed M. F. (2003). Treatment of arsenic contaminated water. In Ahmed M. F. (Ed.), Arsenic Contamination: Bangladesh Perspective. Dhaka: ITN-Bangladesh, Centre for Water Supply and Waste management, BUET.

ALCAN (2006) Private communication.

Ali M. A., Badruzzaman A. B. M., Jalil M. A., Hossain M. D., Hossainuzzaman M. M., Badruzzaman M., Mohammad and O. I. Akhter (2001). Development of low-cost technologies for removal of arsenic from groundwater. In Ahmed, M. F. Ali, M. A. Adeel, Z. (Eds.), Technologies for Arsenic Removal from Drinking Water. Dhaka: Bangladesh University of Engineering Technology and the United Nations University.

Centeno J. A., Mullick F. G., Martinez L., Page N. P., Gibb H., Longfellow D., Thompson and C. Ladich E. R. (2002). Pathology related to chronic arsenic exposure. Environ. Health Perspect. 110: 883-886.

Cheng Z., Van Green A.., Jing C., Meng X., Seddigue A. and Ahmed K. M. (2004). Performance of a householdlevel arsenic removal system during 4-month deployment in Bangladesh, Environ. Sci. Technol. 38: 3442 3448 .

Clesceri L. S., Greenberg A. E. and Eaton A. D. (Eds.). (1998). Standard Methods for the Examination of Water and Wastewater (20th ed.). Washington: American Public Health Association.

Dzomback D. A. and Mofrel F. M. M. (1990). Surface Complexation Modeling: Hydrous Ferric Oxide. New York: John Wiley and Sons, Inc.

GoB (1997). The Environment Conservation Rules: Schedule 3, Government of the People's Republic of Bangladesh. Ministry of Environment and Forest.

Heikens A. (2006). Arsenic contamination of irrigation water, soil and crops in Bangladesh: Risk implications for sustainable agriculture and food safety in Asia. Bangkok: Food and Agriculture Organization of the United Nations. Retrieved June 12, 2008 from: ftp://ftp.fao.org/docrep/fao/009/ag105e/ag105e00.pdf

Hussam A., Habibuddowla M., Alauddin M., Hossain Z. A., Munir A. K. and M. Khan A. H. (2003). Chemical Fate of Arsenic and Other metals in Groundwater of Bangladesh: Experimental Measurement and Chemical Equilibrium Model. J. Environ. Sci., 38: 71-86.
Loewenberg, S. (2007). Scientists tackle water contamination in Bangladesh. Lancet, 370: 471-472.

Meeussen, J. C. L.Heimstra, T. Van Riemsdijk, W. H. and Borkovec M. (1996). Predicting Multicomponent Adsorption and Transport of Fluoride at Variable pH in a Goethite-Silica Sand System. Environ. Sci. Technol., 30: 48 - 488 .

Meng, X. G. Bang, S. Korfiatis, G. P. (2000). Effect of silicate, sulfate, and carbonate on arsenic removal by ferric chloride. Water Res., 34: 1255-1261.

Meng, X. and Korfiatis G. P. (2001). Removal of arsenic from Bangladesh well water using a household filtration system. In Ahmed, M. F., Ali M. A. and Adeel Z. (Eds.), Technologies for Arsenic Removal from Drinking Water. Dhaka: Bangladesh University of Engineering Technology and the United Nations University.

Meng X. G., Korfiatis G. P., Chistodoulos C. and Bang C. (2001). Water Res., 35: 2805-2810.

Mukherjee P., Chatterjee D., Jana J., Maity P. B., Goswami A., Sha H., Sen M., Nath B., Shome D., Joyti Sarka M. and Bagchi D. (2007). Household water treatment option:removal of arsenic in presence of natural Fecontaining groundwater by solar oxidation. In Bhattachara, P., Mukherjee, A. B., Bundschuh, J., Zevenhoven, R., and Loeppert R. H. (Eds.), Trace Metals and other Contaminants in the Environment, 9: 604-622.

Pal B. N. (2001). Granular ferric Hydroxide for Elimination of Arsenic from Drinking Water. In Ahmed, M. F., Ali M. A. and Adeel Z. (Eds.), Technologies for Arsenic Removal from Drinking Water. Dhaka: Bangladesh University of Engineering Technology and the United Nations University.

Pierce M. L. and Moore C. B. (1982). Adsorption of arsenite and arsenate on amorphous iron hydroxide. Water Res., 16: 1247-1253.

Roberts L. C., Hug, S. J., Ruettimann T. Billah M. M., Khan A. W. and Rahman. M. T. (2004). Arsenic Removal with Iron (II) and Iron (III) in Waters with High Silicate and Phosphate Concentrations. Environ. Sci. Technol., 38: 307-315.

Stumm W. and Morgan J. J. (1996). Aquatic Chemistry. New York: John Wiley and Sons, Inc.

Received : November 10, 2008;

Accepted : March 14, 2010 